\title{
Article
}

\section{Incidence Hypertension and Fasting Blood Glucose from Real-World Data: Retrospective Cohort for 7-Years Follow-Up}

\author{
Soon-Ki Ahn ${ }^{1,+}{ }^{\mathbb{D}}$, Ju-Mi Lee ${ }^{2,+}$, Seon Mi Ji ${ }^{3, *}$, Kyoung Hoon Kim ${ }^{4}$, Jong-Heon Park ${ }^{3}$ and Min Kyung Hyun ${ }^{5}$ \\ 1 Public Health and Medical Services Office, Chungnam National University Hospital, Jung-gu, \\ Daejeon 35015, Korea; withspirit09@gmail.com \\ 2 Department of Preventive Medicine, Eulji College of Medicine, Daejeon 34824, Korea; \\ aqualeo0731@gmail.com \\ National Health Insurance Service, Wonju 26464, Korea; parkjh@nhis.or.kr \\ 4 Health Insurance Review \& Assessment Service, Wonju 26465, Korea; rudqnr@hanmail.net \\ 5 Department of Preventive Medicine, College of Korean Medicine, Dongguk University, \\ Gyeongju-si 38066, Korea; mk3three@dongguk.ac.kr \\ * Correspondence: bleupink@nhis.or.kr \\ + Shared first authorship/equal contributions.
}

check for

updates

Citation: Ahn, S.-K.; Lee, J.-M.; Ji, S.M.; Kim, K.H.; Park, J.-H.; Hyun, M.K. Incidence Hypertension and Fasting Blood Glucose from Real-World Data: Retrospective Cohort for 7-Years Follow-Up. Int. J Environ. Res. Public Health 2021, 18, 2085. https://doi.org/10.3390/ ijerph18042085

Academic Editor: Paul B. Tchounwou

Received: 30 January 2021

Accepted: 15 February 2021

Published: 21 February 2021

Publisher's Note: MDPI stays neutral with regard to jurisdictional claims in published maps and institutional affiliations.

Copyright: (c) 2021 by the authors. Licensee MDPI, Basel, Switzerland. This article is an open access article distributed under the terms and conditions of the Creative Commons Attribution (CC BY) license (https:/ / creativecommons.org/licenses/by/ $4.0 /)$.

\begin{abstract}
This retrospective cohort study was done to investigate the incidence of hypertension and its relation to the fasting blood glucose level in Korea. The eligible non-hypertensive subjects $(n=3,396,187)$ among the National Health Insurance Service-National Health Screening (NHISHEALS) examinees $(n=10,644,911)$ in 2009 were followed up until 2015. A Cox proportional hazards regression was used to estimate the risk of the high blood glucose level for the incident hypertension while controlling for covariates' confounding effect. The cumulative incidence rate was $10.6 \%$ for seven years (11.6\% in men and $8.3 \%$ in women). The incidence density was 1474.8 per 100,000 personyears. High fasting blood glucose (adjusted Hazard Ratio (aHR), 1.836; 95\% confidence interval (CI), 1.810 to 1.862 ), prediabetes (aHR, 1.249; 95\% CI, 1.237 to 1.260), a history of diabetes mellitus (aHR, 1.635; 95\% CI, 1.605 to 1.666), high triglyceride (aHR, 1.292; 95\% CI, 1.280 to 1.303), a history of dyslipidemia (aHR, 1.279; 95\% CI, 1.253 to 1.305) and prehypertension group (aHR, 1.964; 95\% CI, 1.948 to 1.979 ) were significantly related to the incident hypertension after adjusting for covariates. Among real-world data in Korea, high blood glucose level was the independent risk factor for developing hypertension.
\end{abstract}

Keywords: incidence; hypertension; blood glucose; prediabetic state; prehypertension

\section{Introduction}

Hypertension is the third leading risk factor for the global burden of disease and the leading risk factor for cardiovascular and kidney disease [1-4]. About 54\% of stroke and $47 \%$ of ischemic heart disease worldwide were attributable to high blood pressure [5]. The estimated total number of adults with hypertension in 2000 was 972 million (957987 million), and it was projected to increase by $60 \%$ to a total of 1.56 billion (1.54 billion1.58 billion) in 2025 worldwide [6]. According to the 2018 Health Insurance Statistical Yearbook, there are 6.31 million hypertensive patients in Korea that use 333.29 billion won for medical expenses, and patients increased by $4.2 \%$ compared to the previous year and $7.1 \%$ the prior year [7]. Hypertension is two times more common among patients with diabetes than those without diabetes, so strict blood pressure control needs to be a high priority in caring for patients with type 2 diabetes [8].

Meanwhile, prediabetes is defined as the presence of IFG (impaired fasting glucose) or IGT (impaired glucose tolerance) or raised HbA1c (5.7-6.4\% by ADA 2010 criteria). Prediabetes is not only a clinical entity in itself, it should be considered an increased risk of diabetes and cardiovascular disease (CVD) [9,10]. However, evidence is less clear regarding 
hypertension mediating the causative relationship between prediabetes and CVD [11]. Prediabetes and hypertension induce endothelial dysfunction and inflammation by elevating levels of soluble adhesion molecules and inflammatory cytokines. The comorbidity of these diseases may exacerbate inflammation and endothelial dysfunction [12]. According to the American Heart Association (AHA), lifestyle factors such as body mass index, physical activity, diet, and cigarette smoking are critical determinants of blood pressure levels $[13,14]$. Several factors contribute to an accelerated diabetes epidemic, including the obesity phenotype; high prevalence of smoking and heavy alcohol use; high intake of refined carbohydrates; and dramatically decreased physical activity levels [15].

Fasting plasma glucose in the prediabetes range is independently and significantly associated with the future development of hypertension [16]. It is essential to pay attention to the early stage of hypertension and diabetes, to control the transition from prehypertension and prediabetes to hypertension and diabetes [17]. Although many studies of prevalence and incidence of hypertension have been conducted in various sample sizes, areas or workplaces, and age groups [18,19], there is limited research on prediabetes on development of hypertension with a nationwide scale in Korea.

Therefore, this study was conducted to investigate the incidence of hypertension and its relation to the fasting glucose level among non-hypertensive national health examinees in Korea.

\section{Materials and Methods}

\subsection{Data Source}

Korean National Health Insurance Service (NHIS) is the only insurer, covering approximately $96.6 \%$ of the entire South Korean population, and has a claim database and general health examination database. This retrospective observational cohort study used the National Health Screening (HEALS) and NHIS database. The HEALS Program invites individuals to participate at least once every 2 years in a general free-of-charge health screening program. HEALS and NHIS databases are linked to personal identification numbers and anonymized and provided to a designated secure computer in the security room.

The National Health Insurance Service-National Health Screening (NHIS-HEALS) database includes medical diagnoses, drug prescriptions, demographic characteristics, and information from health examinations, such as self-administered health surveys, physical examinations, and biochemical test results. Details of the cohort have been published previously [20-23].

\subsection{Study Design}

Briefly, study candidates were 10,644,911 individuals aged over 19 years old who participated in HEALS between 1 January 2009, and 31 December 2009. Due to the study aim, individuals were excluded if they had baseline (2009) blood pressure (BP) values of $\geq 140 \mathrm{mmHg}$ systolic or $\geq 90 \mathrm{mmHg}$ diastolic, or a diagnosis of hypertension (International Classification of Disease-Tenth Revision, Clinical Modification Code (ICD-10-CM:) I10, 11, $12,13,15)$. After that, all participants were categorized in normal or high-normal blood pressure categories based on the national health examination in 2009.

Persons with a history of ischemic heart diseases (ICD-10-CM: I20 to 25), cerebrovascular (ICD-10-CM: I60 to 69), or other peripheral vascular diseases (ICD-10-CM: I70 to 79) were excluded because of the possible effect of such diseases on accurate blood pressure. Persons with a history of malignancy (ICD-10-CM: C00 to 97) and missing data which did not meet the inclusion criteria were excluded (Figure 1). Finally, 3,396,187 nonhypertensive subjects were our retrospective cohort participants and followed up for seven years until 2015. 


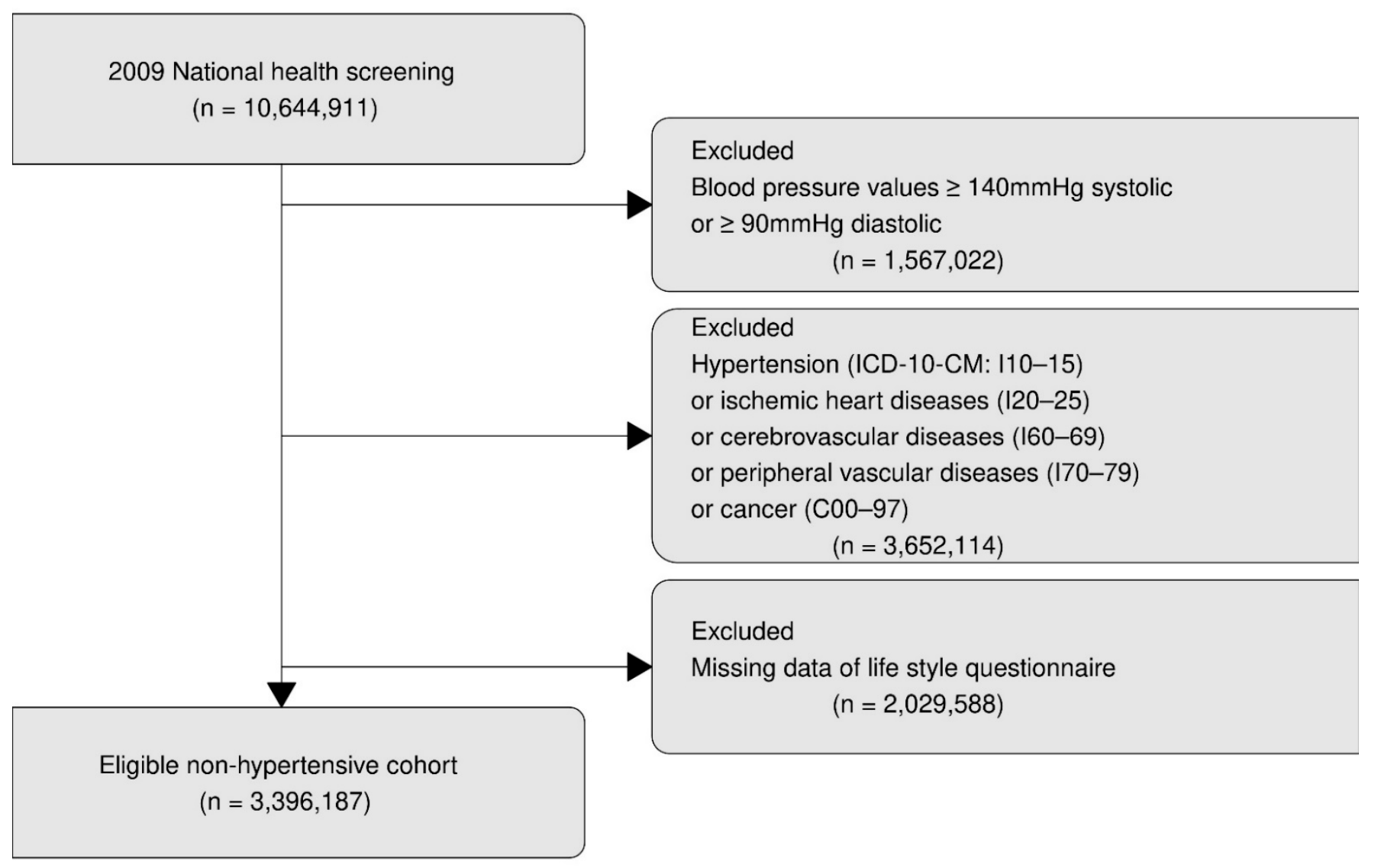

Figure 1. Flowchart of study participants.

\subsection{Outcome Variable}

The primary endpoint was identified based on ICD-10-CM codes (I10, I11, I12, I13, and I15) in the medical record from the NHIS database.

\subsection{Independent Variables}

Blood samples were taken using a venipuncture during the health examination after an overnight fast of at least $8 \mathrm{~h}$. Total cholesterol, serum glucose, triglycerides (TG), and high-density lipoprotein (HDL) cholesterol were enzymatically assessed. Body mass index (BMI) was estimated as body weight $(\mathrm{kg})$ divided by height squared $\left(\mathrm{m}^{2}\right)$.

Study subjects were classified by measured fasting blood glucose levels into 3 groups ( $\geq 126 \mathrm{mg} / \mathrm{dL} ; 100-125 \mathrm{mg} / \mathrm{dL} ;<100 \mathrm{mg} / \mathrm{dL}$ ) based on a classification and diagnosis of diabetes using the standards of medical care in diabetes of the American Diabetes Association (ADA) in 2018 [9]. For the present study, prehypertension was identified as systolic blood pressure (BP) levels in the range of 120 to $139 \mathrm{mmHg}$ or diastolic BP between 80 and $89 \mathrm{mmHg}$, according to the Seventh Joint National Committee on the Prevention, Detection, Evaluation, and Treatment of Hypertension (JNC-VII) [24].

Metabolic syndrome was defined in subjects with three or more of the following criteria: (1) Abdominal obesity, waist circumference $\geq 90 \mathrm{~cm}$ in men or $\geq 80 \mathrm{~cm}$ in women; (2) Hypertriglyceridemia, TG $\geq 150 \mathrm{mg} / \mathrm{dL}$ or medication use; (3) Low HDL-cholesterol, HDL-cholesterol $<40 \mathrm{mg} / \mathrm{dL}$ in men and $<50 \mathrm{mg} / \mathrm{dL}$ in women; (4) High systolic blood pressure (BP), systolic $\mathrm{BP} \geq 130 \mathrm{mmHg}$ and/or diastolic $\mathrm{BP} \geq 85 \mathrm{mmHg}$; (5) Hyperglycemia, fasting blood glucose $>100 \mathrm{mg} / \mathrm{dL}$ or use [25].

Current smokers were identified as those who had smoked more than 100 cigarettes in their lives or were currently smoking. High-risk drinking was defined as drinking more than $300 \mathrm{~mL}$ per day on average. For traditional Korean drinks, one standard drink unit corresponds to one bowl (approximately $300 \mathrm{~mL}$ ) of Korean rice beer (Makgeolli) or a 
quarter bottle (approximately $90 \mathrm{~mL}$ ) of 20\% Korean liquor (Soju) [26]. The optimal exercise was identified as follows: (1) intensive exercise lasting more than 20 min per session and more than three times per week or (2) moderate exercise lasting more than 30 min per session and more than five times per week. Household income was calculated based on the insurance owner's income level to claim health insurance premiums and was classified into quintiles.

\subsection{Statistical Analysis}

The continuous variables were reported as the mean value \pm standard deviation (SD) and compared using a Student t-test. The categorical variables were presented as the frequency and proportion (\%) and compared using a chi-squared test. The incidence density of newly diagnosed hypertension per 100,000 person-years (PY) was calculated as the number of participants who developed new onset of hypertension during the follow-up period divided by the sum of individual follow-up periods of those at risk.

Multicollinearity among covariates was evaluated by assessing deviations of regression coefficients and their standard errors (SEs) in the fitted multivariate models, but none were detected.

Cox proportional hazards regression was used to estimate the prognostic influence of non-hypertension on conversion to hypertension while simultaneously controlling for covariates' confounding effects. Non-hypertensive subjects were divided into two groups for the multivariate proportional hazard regression models: the normotensive and the pre-hypertensive. The adjusted hazard ratio (aHR) and 95\% confidence interval (CI) are reported. A two-sided probability value less than 0.05 were considered statistically significant. Data was analyzed with SAS statistical software, version 9.4, for Windows (SAS, Cary, NC) and R software (version 4.0.2, the R Foundation for Statistical Computing, Vienna, Austria, http:/ / www.r-project.org).

\section{Results}

\subsection{Baseline Characteristics of the Study Participants}

The baseline characteristics of the study participants are shown in Table 1. Among the 3,396,187 total subjects, the proportion of men was 70.7\%. Excluding the metabolic syndrome variable, all the proportions of the other variables were statistically significantly higher in men than in women $(p<0.001)$.

Table 1. Baseline characteristics of study participants.

\begin{tabular}{|c|c|c|c|c|}
\hline Variables/Subgroups & $\begin{array}{c}\text { Total } \\
(n=3,396,187)\end{array}$ & $\begin{array}{c}\text { Men } \\
(n=2,399,713,70.7 \%)\end{array}$ & $\begin{array}{c}\text { Women } \\
(n=996,474,29.3 \%)\end{array}$ & $p$-Value \\
\hline $\begin{array}{c}\text { Age (years) } \\
(\text { Mean } \pm \text { SD) }\end{array}$ & $38.1 \pm 11.0$ & $38.6 \pm 10.8$ & $37.0 \pm 11.5$ & $<0.0001$ \\
\hline \multicolumn{5}{|c|}{ Fasting blood glucose level (mg/dL) } \\
\hline$<100$ & $2,570,560(75.7)$ & $1,734,786(72.3)$ & $835,774(83.9)$ & $<0.0001$ \\
\hline $100-125$ & $717,924(21.1)$ & $571,748(23.8)$ & $146,176(14.7)$ & \\
\hline$\geqq 126$ & $107,703(3.2)$ & $93,179(3.9)$ & $14,524(1.5)$ & \\
\hline \multicolumn{5}{|l|}{ Systolic BP (mmHg) } \\
\hline$<120$ & $1,626,329(47.9)$ & $963,848(40.2)$ & $662,481(66.5)$ & $<0.0001$ \\
\hline $120-139$ & $1,769,858(52.1)$ & $1,435,865(59.8)$ & $333,993(33.5)$ & \\
\hline \multicolumn{5}{|l|}{ Diastolic BP (mmHg) } \\
\hline$<80$ & $2,115,361(62.3)$ & $1,345,291(56.1)$ & $770,070(77.3)$ & $<0.0001$ \\
\hline 80-89 & $1,280,826(37.7)$ & $1,054,422(43.9)$ & $226,404(22.7)$ & \\
\hline $\begin{array}{l}\text { BMI }\left(\mathrm{kg} / \mathrm{m}^{2}\right) \\
(\text { Mean } \pm \mathrm{SD})\end{array}$ & $23.3 \pm 3.1$ & $23.8 \pm 3.0$ & $22.1 \pm 3.1$ & $<0.0001$ \\
\hline \multicolumn{5}{|l|}{ Waist circumference $(\mathrm{cm})$} \\
\hline Men $<90$, Women $<85$ & $2,944,248(86.7)$ & $2,025,580(84.4)$ & $918,668(92.2)$ & $<0.0001$ \\
\hline Men $\geqq 90$, Women $\geqq 85$ & $451,939(13.3)$ & $374,133(15.6)$ & $77,806(7.8)$ & \\
\hline
\end{tabular}


Table 1. Cont.

\begin{tabular}{|c|c|c|c|c|}
\hline Variables/Subgroups & $\begin{array}{c}\text { Total } \\
(n=3,396,187)\end{array}$ & $\begin{array}{c}\text { Men } \\
(n=2,399,713,70.7 \%)\end{array}$ & $\begin{array}{c}\text { Women } \\
(n=996,474,29.3 \%)\end{array}$ & $p$-Value \\
\hline \multicolumn{5}{|l|}{ Triglyceride (mg/dL) } \\
\hline$<150$ & $2,436,931(71.8)$ & $1,542,728(64.3)$ & $894,203(89.7)$ & $<0.0001$ \\
\hline$\geqq 150$ & $959,256(28.3)$ & $856,985(35.7)$ & $102,271(10.3)$ & \\
\hline \multicolumn{5}{|l|}{$\operatorname{HDL}(\mathrm{mg} / \mathrm{dL})$} \\
\hline Men $<40$, Women $<50$ & $470,338(13.9)$ & $287,031(12.0)$ & $183,307(18.4)$ & $<0.0001$ \\
\hline Men $\geqq 40$, Women $\geqq 50$ & $2,925,849(86.2)$ & $2,112,682(88.0)$ & $813,167(81.6)$ & \\
\hline \multicolumn{5}{|l|}{ History of diabetes mellitus } \\
\hline No & 3,341,335 (98.4) & $2,351,550(98.0)$ & $989,785(99.3)$ & $<0.0001$ \\
\hline Yes & $54,852(1.6)$ & $48,163(2.0)$ & $6689(0.7)$ & \\
\hline \multicolumn{5}{|l|}{ History of dyslipidemia } \\
\hline No & $3,332,463(98.1)$ & $2,345,162(97.7)$ & $987,301(99.1)$ & $<0.0001$ \\
\hline Yes & $63,724(1.9)$ & $54,551(2.3)$ & $9173(0.9)$ & \\
\hline \multicolumn{5}{|l|}{ Metabolic syndrome } \\
\hline No & $1,360,773(40.1)$ & $1,147,127(47.8)$ & $213,646(21.4)$ & $<0.0001$ \\
\hline Yes & $2,035,414(59.9)$ & $1,252,586(52.2)$ & $782,828(78.6)$ & \\
\hline \multicolumn{5}{|l|}{ Current smoking } \\
\hline No & 2,018,092 (59.4) & $1,084,540(45.2)$ & $933,552(93.7)$ & $<0.0001$ \\
\hline Yes & $1,378,095(40.6)$ & $1,315,173(54.8)$ & $62,922(6.3)$ & \\
\hline \multicolumn{5}{|l|}{ High risk alcohol drinking } \\
\hline No & $2,972,682(87.5)$ & $2,006,597(83.6)$ & $966,085(97)$ & $<0.0001$ \\
\hline Yes & $423,505(12.5)$ & $393,116(16.4)$ & $30,389(3.1)$ & \\
\hline \multicolumn{5}{|l|}{ Optimal exercise } \\
\hline No & $2,812,478(82.8)$ & $1,952,078$ (81.4) & $860,400(86.3)$ & $<0.0001$ \\
\hline Yes & $583,709(17.2)$ & $447,635(18.7)$ & $136,074(13.7)$ & \\
\hline \multicolumn{5}{|l|}{ Household income } \\
\hline 1Q (lowest) & $519,078(15.3)$ & $314,804(13.1)$ & $204,274(20.5)$ & $<0.0001$ \\
\hline $2 Q$ & $618,641(18.2)$ & $366,173(15.3)$ & $252,468(25.3)$ & \\
\hline $3 \mathrm{Q}$ & 767,447 (22.6) & $543,158(22.6)$ & $224,289(22.5)$ & \\
\hline $4 Q$ & $801,814(23.6)$ & $623,335(26)$ & 178,479 (17.9) & \\
\hline 5Q (highest) & $689,207(20.3)$ & $552,243(23)$ & $136,964(13.7)$ & \\
\hline
\end{tabular}

Abbreviations: BP = Blood Pressure; BMI = Body Mass Index; HDL, High-Density Lipoprotein cholesterol.

The mean age was $38.1 \pm 11.0$ years old ( $38.6 \pm 10.8$ years in men and $37.0 \pm 11.5$ years in women). The mean BMI was $23.3 \pm 3.1 \mathrm{~kg} / \mathrm{m} 2(23.8 \pm 3.0$ years for men and $22.1 \pm 3.1$ years for women).

The proportion of prediabetes with fasting blood glucose levels between $100-125 \mathrm{mg} / \mathrm{dL}$ was $23.8 \%$ in men and $14.7 \%$ in women, and that with high fasting blood glucose levels $\geqq 126 \mathrm{mg} / \mathrm{dL}, 3.9 \%$ in men, and $1.5 \%$ in women.

The proportion of systolic blood pressure levels between $120-139 \mathrm{~mm} \mathrm{Hg}$ was $59.8 \%$ in men and $33.5 \%$ in women, and that with diastolic blood pressure level between $80-89 \mathrm{~mm}$ $\mathrm{Hg}$ was $43.9 \%$ in men and $22.7 \%$ in women. History of diabetes mellitus was $2.0 \%$ in men and $0.7 \%$ in women, and history of dyslipidemia was $2.3 \%$ in men and $0.9 \%$ in women.

In addition, $54.8 \%$ of men, and $6.3 \%$ of women subjects were categorized as current smokers. High risk drinking was assessed in $16.4 \%$ of men and $3.1 \%$ in women. Optimal exercise was assessed in $18.7 \%$ of men and $13.7 \%$ of women. The highest household income level was $23.0 \%$ in men and $13.7 \%$ in women.

The proportion of metabolic syndrome was $52.2 \%$ in men and $78.6 \%$ in women $(p<0.001)$.

\subsection{Baseline Characteristics between the New-Onset Hypertension and Non-Hypertensive Group} with the Cumulative Incidence

Table 2 shows the baseline characteristics between the new-onset hypertension and non-hypertensive group with the cumulative incidence. During the study, 360,346 new cases of hypertension were recorded among 3,396,187 participants. The cumulative inci- 
dence rate was $10.6 \%$ for 7 years (11.6\% in men and $8.3 \%$ in women). The mean age of the new-onset hypertension cases was $46.4 \pm 11.5$ years old. The cumulative incidence rate of prediabetes was $14.4 \%$, high fasting blood glucose was $29.0 \%$, systolic blood pressure level between 120-139 $\mathrm{mm} \mathrm{Hg}$ was $14.7 \%$, and diastolic blood pressure level $80-89 \mathrm{~mm} \mathrm{Hg}$ was $15.8 \%$. The cumulative incidence rate of history of diabetes mellitus was $29.6 \%$, history of dyslipidemia was $18.5 \%$, metabolic syndrome was $8.0 \%$, lowest house income level was $11.3 \%$, and highest house income level was $12.9 \%$.

Table 2. Baseline characteristics between new-onset hypertension and non-hypertensive group with the cumulative incidence.

\begin{tabular}{|c|c|c|c|}
\hline Variables/Subgroups & $\begin{array}{c}\text { New-Onset } \\
(n=360,346,10.6 \%)\end{array}$ & $\begin{array}{c}\text { Undiagnosed } \\
(n=3,035,841,89.4 \%)\end{array}$ & $p$-Value \\
\hline \multicolumn{4}{|l|}{ Sex } \\
\hline Men & $277,760(11.6)$ & $2,121,953(88.4)$ & $<0.0001$ \\
\hline Women & $82,586(8.3)$ & $913,888(91.7)$ & \\
\hline $\begin{array}{c}\text { Age (years) } \\
(\text { Mean } \pm \text { SD) }\end{array}$ & $46.4 \pm 11.5$ & $37.1 \pm 10.5$ & $<0.0001$ \\
\hline \multicolumn{4}{|c|}{ Fasting blood glucose level (mg/dL) } \\
\hline$<100$ & $225,930(8.8)$ & $2,344,630(91.2)$ & $<0.0001$ \\
\hline $100-125$ & $103,161(14.4)$ & $614,763(85.6)$ & \\
\hline$\geqq 126$ & $31,255(29.0)$ & $76,448(71.0)$ & \\
\hline \multicolumn{4}{|l|}{ Systolic BP (mmHg) } \\
\hline$<120$ & $99,746(6.1)$ & $1,526,583(93.9)$ & $<0.0001$ \\
\hline $120-139$ & $260,600(14.7)$ & $1,509,258(85.3)$ & \\
\hline \multicolumn{4}{|l|}{ Diastolic BP (mmHg) } \\
\hline$<80$ & $158,271(7.5)$ & $1,957,090(92.5)$ & $<0.0001$ \\
\hline 80-89 & $202,075(15.8)$ & $1,078,751(84.2)$ & \\
\hline $\begin{array}{l}\text { BMI }\left(\mathrm{kg} / \mathrm{m}^{2}\right) \\
(\text { Mean } \pm \mathrm{SD})\end{array}$ & $24.5 \pm 3.1$ & $23.2 \pm 3.1$ & $<0.0001$ \\
\hline \multicolumn{4}{|l|}{ Waist circumference (cm) } \\
\hline Men $<90$, Women $<85$ & $273,573(9.3)$ & $2,670,675(90.7)$ & $<0.0001$ \\
\hline Men $\geqq 90$, Women $\geqq 85$ & $86,773(19.2)$ & $365,166(80.8)$ & \\
\hline \multicolumn{4}{|l|}{ 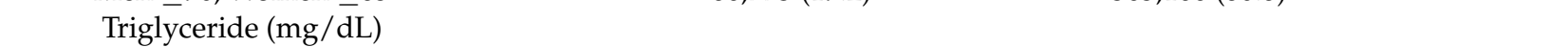 } \\
\hline$<150$ & $215,102(8.8)$ & $2,221,829(91.2)$ & $<0.0001$ \\
\hline$\geqq 150$ & $145,244(15.1)$ & $814,012(84.9)$ & \\
\hline \multicolumn{4}{|l|}{$\operatorname{HDL}(\mathrm{mg} / \mathrm{dL})$} \\
\hline Men $<40$, Women $<50$ & $60,753(12.9)$ & $409,585(87.1)$ & $<0.0001$ \\
\hline Men $\geqq 40$, Women $\geqq 50$ & $299,593(10.2)$ & $2,626,256(89.8)$ & \\
\hline \multicolumn{4}{|l|}{ History of diabetes mellitus } \\
\hline No & $344,095(10.3)$ & $2,997,240(89.7)$ & $<0.0001$ \\
\hline Yes & $16,251(29.6)$ & $38,601(70.4)$ & \\
\hline \multicolumn{4}{|l|}{ History of Dyslipidemia } \\
\hline No & $348,566(10.5)$ & 2,983,897 (89.5) & $<0.0001$ \\
\hline Yes & $11,780(18.5)$ & $51,944(81.5)$ & \\
\hline \multicolumn{4}{|l|}{ Metabolic syndrome } \\
\hline No & $196,822(14.5)$ & $1,163,951(85.5)$ & $<0.0001$ \\
\hline Yes & $163,524(8.0)$ & $1,871,890(92.0)$ & \\
\hline \multicolumn{4}{|l|}{ Current smoking } \\
\hline No & $211,367(10.5)$ & $1,806,725$ (89.5) & $<0.0001$ \\
\hline Yes & $148,979(10.8)$ & $1,229,116(89.2)$ & \\
\hline \multicolumn{4}{|l|}{ High risk alcohol drinking } \\
\hline No & $299,332(10.1)$ & $2,673,350(89.9)$ & $<0.0001$ \\
\hline Yes & $61,014(14.4)$ & $362,491(85.6)$ & \\
\hline \multicolumn{4}{|l|}{ Optimal exercise } \\
\hline No & $287,381(10.2)$ & $2,525,097(89.8)$ & $<0.0001$ \\
\hline Yes & $72,965(12.5)$ & $510,744(87.5)$ & \\
\hline
\end{tabular}


Table 2. Cont.

\begin{tabular}{|c|c|c|c|}
\hline Variables/Subgroups & $\begin{array}{c}\text { New-Onset } \\
(n=360,346,10.6 \%)\end{array}$ & $\begin{array}{c}\text { Undiagnosed } \\
(n=3,035,841,89.4 \%)\end{array}$ & $p$-Value \\
\hline \multicolumn{4}{|l|}{ Household income } \\
\hline 1Q (lowest) & $58,639(11.3)$ & $460,439(88.7)$ & $<0.0001$ \\
\hline $2 Q$ & $56,659(9.2)$ & $561,982(90.8)$ & \\
\hline $3 \hat{Q}$ & $71,786(9.4)$ & $695,661(90.7)$ & \\
\hline $4 \mathrm{Q}$ & $84,722(10.6)$ & $717,092(89.4)$ & \\
\hline 5Q (highest) & $88,540(12.9)$ & $600,667(87.2)$ & \\
\hline
\end{tabular}

Abbreviations: $\mathrm{BP}$ = blood pressure; $\mathrm{BMI}$ = body mass index; $\mathrm{HDL}$ = high-density lipoprotein cholesterol.

\subsection{Incidence Density of New Incident Hypertension}

Table 3 shows the incidence density of new incident hypertension was 1474.8 per 100,000 person-year (PY). Accordingly, the calculated total observation years were 21,037,305.5 PY. Within our observation period, 360,346 subjects were diagnosed with new incident hypertension.

Table 3. Incidence density of new-onset hypertension by year.

\begin{tabular}{cccccc}
\hline $\begin{array}{c}\text { Follow-Up Period } \\
\text { (Years) }\end{array}$ & $\begin{array}{c}\text { Population at } \\
\text { Risk (n) }\end{array}$ & $\begin{array}{c}\text { New-Onset } \\
\text { Hypertension (n, \%) }\end{array}$ & Censored (n) & PY & $\begin{array}{c}\text { Incidence (per } \\
\mathbf{1 0 0 , 0 0 0 ~ P Y ) ~}\end{array}$ \\
\hline $0-1$ & $3,396,187$ & $51,247(1.51)$ & 2620 & $3,394,877$ & 1509.0 \\
$1-2$ & $3,342,320$ & $55,942(1.67)$ & 3066 & $3,340,787$ & 1647.8 \\
$2-3$ & $3,283,312$ & $57,250(1.74)$ & 3437 & $3,281,593.5$ & 1713.7 \\
$3-4$ & $3,222,625$ & $56,043(1.74)$ & 3418 & $3,220,916$ & 1707.8 \\
$4-5$ & $3,163,164$ & $56,460(1.78)$ & 3247 & $3,161,540.5$ & 1752.9 \\
$5-6$ & $3,103,457$ & $56,420(1.82)$ & 2876 & $3,102,019$ & 1784.6 \\
$6-7$ & $3,044,161$ & $26,984(0.89)$ & $3,017,177$ & $1,535,572.5$ & 869.9 \\
total & $3,396,187$ & $360,346(10.61)$ & $3,035,841$ & $21,037,305.5$ & 1474.8 \\
\hline
\end{tabular}

Abbreviations: PY = Person-Year.

The multivariate Cox regression analysis for identifying independent risk factors of newly diagnosed hypertension and its forest plot is presented in Figure 2. In the multivariate model, high fasting blood glucose (adjusted Hazard Ratio (aHR), 1.836; 95\% confidence interval (CI), 1.810 to 1.862), prediabetes (aHR, 1.249; 95\% CI, 1.237 to 1.260), a history of diabetes mellitus (aHR, 1.635; 95\% CI, 1.605 to 1.666), high triglyceride (aHR, 1.292; 95\% CI, 1.280 to 1.303), a history of dyslipidemia (aHR, 1.279; 95\% CI, 1.253 to 1.305), and prehypertension group (aHR, 1.964; 95\% CI, 1.948 to 1.979) were significantly related to the incident hypertension after adjusting for age, sex, body mass index, waist circumference, HDL-cholesterol, metabolic syndrome, current smoking, high-risk alcohol drinking, optimal exercise, and household income (Supplementary Table S1). 
Variables/Subgroups

Fasting blood glucose level (mg/dl)

$<100$
$100-125$
$\geqq 126$
Blood pressure group
Normotensive
Pre-hypertensive
History of diabetes mellitus
No
Yes
Triglyceridemg (mg/dl)
$<150$
$\geqq 150$
History of Dyslipidemia
No
Yes

$\operatorname{aHR}(95 \% \mathrm{Cl})$

$p$-Value

\author{
Ref
}

$1.249(1.237-1.260)$

$1.836(1.810-1.862)$

$<0.0001$

$<0.0001$

Ref

$1.964(1.948-1.979) \quad<0.0001$

Ref

$1.635(1.605-1.666) \quad<0.0001$

Ref

$1.292(1.280-1.303) \quad<0.0001$

Ref

$1.279(1.253-1.305) \quad<0.0001$

$\begin{array}{lll}0.8 & 1.0 & 2.0\end{array}$

Figure 2. Forest plot of the adjusted Hazard ratio of incident hypertension. Abbreviations: aHR = adjusted Hazard Ratio; CI = Confidence Interval; Ref = Reference. Adjusted for age, sex, body mass index, waist circumference, highdensity lipoprotein cholesterol, metabolic syndrome, current smoking, high risk alcohol drinking, optimal exercise, and household income.

\section{Discussion}

Our study result showed that high blood glucose levels, such as diabetes level and prediabetic level, were independent risk factors for new-onset hypertension in the National Health Screening examinees in Korea.

During the follow-up study, new-onset hypertension was found in 360,346 people. The cumulative incidence rate was $10.6 \%$ over seven years $(11.6 \%$ for men and $8.3 \%$ for women) at the mean age of 38 . The incidence density of new-onset hypertension was 1474.8 per 100,000 person-years. Compared to the previous studies, one prospective cohort study reported that the cumulative incidence of hypertension in middle-aged Koreans was $17.3 \%$. This difference can be explained by the fact that the study subjects' average age was 50.5 years, which was higher than 38.1 years of age in this study. Like our study, one real-world claimed data study reported that the incidence density of hypertension in middle-aged Koreans was about 50 per 1000 people [27]. This difference can be explained by the fact that the study subjects were 40 years of age or older, which was higher than our study subjects' age.

In 1967, one case-controlled (people with diabetes and an equal number of controls) study showed the prevalence of hypertension was $54 \%$ greater among the people with diabetes [28]. Since then, many studies reported comorbid status and the association between diabetes mellitus and hypertension. Approximately $75 \%$ of patients with diabetes had concomitant hypertension, and both conditions also increased with age [29]. Recently, 
diabetes mellitus was considered a risk factor for hypertension. One study showed diabetes mellitus at baseline was a significant predictor of incident hypertension [30]. All of these results are consistent with our results.

Possible mechanisms in developing hypertension in diabetes mellitus have been continuously suggested. Diabetes and hypertension share common pathways such as the sympathetic nervous system (SNS), renin-angiotensin-aldosterone system (RAAS), oxidative stress, adipokines, insulin resistance, and Peroxisome proliferator-activated receptors (PPARs) [31]. These pathways interact and influence each other. For example, insulin resistance causes hyperglycemia, dyslipidemia, and hyperinsulinemia, leading to vascular smooth muscle cell proliferation, increasing arterial stiffness, vascular tone, sodium retention, sympathetic nervous system, and decreasing vasodilation, thus leading to high blood pressure.

Preclinical stages were associated with new-onset hypertension. This study was consistent with the results of fasting plasma glucose in the prediabetes range, which is independently and significantly associated with future development of hypertension among large scale nationwide research subjects in Korea [18]. In the Korean Genome and Epidemiology Study (KoGES), which followed 10,038 patients for ten years, the incidence of hypertension in the prediabetes group was insignificant compared to the normoglycemia group [11]. In contrast, in the present study, the risk of hypertension was 1.8 times higher in the high fasting blood glucose group and 1.2 times higher in the prediabetes group. The prehypertensive group had about two times the incidence of hypertension than the normotensive group, which was the most potent risk factor in the present study. The previous study reported 2-3 times [27,32], perhaps due to the age difference. Our result is consistent with previous studies [33-35]. Age, sex, body mass index, waist circumference, metabolic syndrome, current smoking, high-risk alcohol drinking, and household income were generally consistent with other studies, but high-density lipoprotein cholesterol and optimal exercise were not. Inconsistent results seem to be the effect of differences in distribution by gender and age. The new-onset hypertension group was more likely to be comprised of female, older, prediabetes, the high fasting blood glucose, history of diabetes mellitus, dyslipidemia, history of dyslipidemia, metabolic syndrome, current smoking, high-risk drinking, and lower household income participants, compared to the non-hypertensive group.

In the present study, diet and water contained minerals were not considered. Higher sodium intake and lower potassium intake are known to play an important role in the development of hypertension $[14,36,37]$. According to previous studies, differences in the age-adjusted prevalence of hypertension across racial and ethnic groups were reported, in the order of non-Hispanic black, non-Hispanic white, Hispanic, and non-Hispanic Asian [14,38-40], but the difference could not be confirmed in the present study because Korea was composed of a single ethnic group.

Our study has several strengths. Our study showed clear insight that diabetes and prediabetes range of blood glucose level are risk factors for developing hypertension with real-world data. Second, our study has the strength of being of large scale with nationwide research subjects, making it easier to generalize the research results. Third, our study design has advantages, such as not being interrupted with recall bias and selective reporting reduction. Fourth, the final model considered AHA's simple seven healthy behavior and social-economic status by adjusting age, sex, blood pressure level, lipid profiles, house income, smoking, drinking, and exercise.

The present study has some limitations. First, we identified the hypertension cases using only claims data, including diagnostic and treatment codes, and could not validate the diagnosis of hypertension through direct review of medical records, which is an inherent limitation of studies using the claim database. Second, due to data limitation, we could not analyze the changes in health status and lifestyle during the follow-up period, and the prediabetes group was defined as just only fasting blood glucose level. Third, there 
were about 2.5 times fewer female samples than males, and gender stratification could not be performed.

\section{Conclusions}

Our study confirmed real-world data that high blood glucose levels were an independent risk factor for developing hypertension among non-hypertensive national health examinees in Korea. This study suggested meaningful insight because it is consistent with other studies' results: well-performed cohort study results and case-controlled study results. This study may present an opportunity to reform the community-based programs for prevention and management that have been in progress in about 250 local health centers in Korea for more than several decades.

A further study may be required to establish cut-off levels for optimal glucose levels for developing incident hypertension. Additionally, laboratory investigations may be required to understand the exact roles of each stage of the pathophysiologic mechanisms in the development of hypertension at a high glucose level.

Supplementary Materials: The following are available online at https:/ /www.mdpi.com/1660-4 601/18/4/2085/s1, Supplementary Table S1: Adjusted Hazard ratio of incident hypertension by baseline characteristics.

Author Contributions: Conceptualization, S.-K.A., J.-M.L., S.M.J., K.H.K., J.-H.P., and M.K.H.; methodology, S.-K.A., J.-M.L., S.M.J., and M.K.H.; validation, S.-K.A., S.M.J., K.H.K., J.-H.P., M.K.H., and J.-M.L.; formal analysis, S.M.J., K.H.K., J.-H.P., and M.K.H.; data curation, K.H.K., J.-H.P., and M.K.H.; writing — original draft preparation, S.-K.A. and J.-M.L.; writing-review and editing, S.K.A., J.-M.L., S.M.J., K.H.K., J.-H.P., and M.K.H.; visualization, S.-K.A.; supervision, S.M.J.; project administration, S.M.J., K.H.K., J.-H.P., and M.K.H. All authors have read and agreed to the published version of the manuscript.

Funding: The authors have no sources of funding to declare.

Institutional Review Board Statement: This study was approved by the Medical University of Dongguk Institutional Review Board (DGU20150010). This study has been carried out in accordance with The Code of Ethics of the World Medical Association (Declaration of Helsinki) for research involving humans.

Informed Consent Statement: Informed consent was exempted because of the total anonymity of all research data used in this study, and we were able to analyze it using a secure computer in the security room of NHIS.

Data Availability Statement: Because of the policy of National Health Insurance Service of Korea, dataset is not permitted to be taken out of the NHIS. The data can be accessed on the National Health Insurance Data Sharing Service homepage of the NHIS (http:/ / nhiss.nhis.or.kr). Applications to use the NHIS-HEALS data will be reviewed by the inquiry committee of research support, and once approved, raw data will be provided to the applicant with a fee. Although the datasets are coded in English and numbers, not in Korean (Hangul), the use of individual data is allowed only for Korean researchers. But it would be possible for researchers outside the country to gain access to the data by conducting a joint study with Korean researchers.

Conflicts of Interest: The authors declare no conflict of interest.

\section{References}

1. Ezzati, M.; Lopez, A.D.; Rodgers, A.; Vander Hoorn, S.; Murray, C.J. Selected major risk factors and global and regional burden of disease. Lancet 2002, 360, 1347-1360. [CrossRef]

2. Stokes, J., 3rd; Kannel, W.B.; Wolf, P.A.; D'Agostino, R.B.; Cupples, L.A. Blood pressure as a risk factor for cardiovascular disease. The Framingham Study-30 years of follow-up. Hypertension 1989. [CrossRef]

3. Klag, M.J.; Whelton, P.K.; Randall, B.L.; Neaton, J.D.; Brancati, F.L.; Ford, C.E.; Shulman, N.B.; Stamler, J. Blood Pressure and End-Stage Renal Disease in Men. N. Engl. J. Med. 1996, 334, 13-18. [CrossRef]

4. O'Seaghdha, C.M.; Perkovic, V.; Lam, T.H.; McGinn, S.; Barzi, F.; Gu, D.F.; Cass, A.; Suh, I.; Muntner, P.; Giles, G.G.; et al. Blood pressure is a major risk factor for renal death: An analysis of 560352 participants from the Asia-Pacific region. Hypertension 2009, 54, 509-515. [CrossRef] 
5. Lawes, C.M.; Hoorn, S.V.; Rodgers, A. Global burden of blood-pressure-related disease, 2001. Lancet 2008, 371, 1513-1518. [CrossRef]

6. Kearney, P.M.; Whelton, M.; Reynolds, K.; Muntner, P.; Whelton, P.K.; He, J. Global burden of hypertension: Analysis of worldwide data. Lancet 2005, 365, 217-223. [CrossRef]

7. Assessment Service, H.I.R.; Service, N.H.I. 2018 National Health Insurance Statistical Yearbook; National Health Insurance Service: Wonju, Korea, 2019; ISBN 1738-8945.

8. De Boer, I.H.; Bangalore, S.; Benetos, A.; Davis, A.M.; Michos, E.D.; Muntner, P.; Rossing, P.; Zoungas, S.; Bakris, G. Diabetes and Hypertension: A Position Statement by the American Diabetes Association. Diabetes Care 2017, 40, 1273-1284. [CrossRef] [PubMed]

9. Association, A.D. 2. Classification and Diagnosis of Diabetes: Standards of Medical Care in Diabetes. Diabetes Care 2018, 41, S13-S27. [CrossRef]

10. Huang, Y.; Cai, X.; Mai, W.; Li, M.; Hu, Y. Association between prediabetes and risk of cardiovascular disease and all cause mortality: Systematic review and meta-analysis. BMJ 2016, 355. [CrossRef] [PubMed]

11. Jung, J.Y.; Oh, C.-M.; Choi, J.-M.; Ryoo, J.-H.; Park, S.K. Long-Term Risk of Hypertension in Normoglycemia and Prediabetes, and Their Relation to the Change of Glycemic State. Am. J. Hypertens. 2018, 31, 1042-1048. [CrossRef] [PubMed]

12. Huang, Z.; Chen, C.; Li, S.; Kong, F.; Shan, P.; Huang, W. Serum Markers of Endothelial Dysfunction and Inflammation Increase in Hypertension with Prediabetes Mellitus. Genet. Test. Mol. Biomark. 2016, 20, 322-327. [CrossRef] [PubMed]

13. Plante, T.B.; Koh, I.; Judd, S.E.; Howard, G.; Howard, V.J.; Zakai, N.A.; Booth, J.N.; Safford, M.M.; Muntner, P.; Cushman, M. Life's Simple 7 and Incident Hypertension: The REGARDS Study. J. Am. Heart Assoc. 2020, 9, e016482. [CrossRef] [PubMed]

14. Benjamin, E.J.; Blaha, M.J.; Chiuve, S.E.; Cushman, M.; Das, S.R.; Deo, R.; De Ferranti, S.D.; Floyd, J.; Fornage, M.; Gillespie, C.; et al. Heart disease and stroke statistics-2017 update: A report from the American Heart Association. Circulation 2017, 135, e146-e603. [CrossRef] [PubMed]

15. Hu, F.B. Globalization of Diabetes: The role of diet, lifestyle, and genes. Diabetes Care 2011, 34, 1249-1257. [CrossRef] [PubMed]

16. Geva, M.; Shlomai, G.; Berkovich, A.; Maor, E.; Leibowitz, A.; Tenenbaum, A.; Grossman, E. The association between fasting plasma glucose and glycated hemoglobin in the prediabetes range and future development of hypertension. Cardiovasc. Diabetol. 2019, 18, 53. [CrossRef] [PubMed]

17. Wang, X.; Wang, M.; Shao, S.; Zhang, Y.; Liu, S.; Gao, Y.; Shen, Y.; Sun, P. Analysis of influencing factor of coexisting prediabetes and prehypertension in adult residents of Jilin Province. BMC Endocr. Disord. 2018, 18, 89. [CrossRef]

18. Lee, S.-H.; Kim, Y.-S.; Sunwoo, S.; Huh, B.-Y. A Retrospective Cohort Study on Obesity and Hypertension Risk among Korean Adults. J. Korean Med. Sci. 2005, 20, 188-195. [CrossRef]

19. Lee, J.H.; Yang, D.H.; Park, H.S.; Cho, Y.; Jun, J.E.; Park, W.H.; Chun, B.Y.; Shin, J.-Y.; Shin, D.H.; Lee, K.S.; et al. Incidence of Hypertension in Korea: 5-Year Follow-up Study. J. Korean Med. Sci. 2011, 26, 1286-1292. [CrossRef]

20. Seong, S.C.; Kim, Y.-Y.; Park, S.K.; Khang, Y.H.; Kim, H.C.; Park, J.H.; Kang, H.-J.; Do, C.-H.; Song, J.-S.; Lee, E.-J.; et al. Cohort profile: The National Health Insurance Service-National Health Screening Cohort (NHIS-HEALS) in Korea. BMJ Open 2017, 7, e016640. [CrossRef]

21. Park, I.-S.; Kang, S.-H.; Kim, Y.-M. Short-term Effects of Health Hazard Factors Changes on the Incidence of Hypertension. Health Soc. Sci. 2016, 42, 85. [CrossRef]

22. Lee, H.J.; Jang, S.-I.; Park, E.-C. Effect of adherence to antihypertensive medication on stroke incidence in patients with hypertension: A population-based retrospective cohort study. BMJ Open 2017, 7. [CrossRef]

23. You, H.-S.; You, N.; Lee, J.-W.; Lim, H.-J.; Kim, J.; Kang, H.-T. Inverse Association between Statin Use and Stomach Cancer Incidence in Individuals with Hypercholesterolemia, from the 2002 NHIS-HEALS Data. Int. J. Environ. Res. Public Health 2020, 17, 1054. [CrossRef] [PubMed]

24. Chobanian Aram, V. Prehypertension Revisited. Hypertension 2006, 48, 812-814. [CrossRef] [PubMed]

25. Alberti, K.G.M.; Zimmet, P.; Shaw, J. The metabolic syndromea new worldwide definition. Lancet 2005, 366, 1059-1062. [CrossRef]

26. Lee, S.; Kim, J.-S.; Jung, J.-G.; Oh, M.-K.; Chung, T.-H.; Kim, J. Korean Alcohol Guidelines for Moderate Drinking Based on Facial Flushing. Korean J. Fam. Med. 2019, 40, 204-211. [CrossRef] [PubMed]

27. Yu, E.S.; Hong, K.; Chun, B.C. Incidence and risk factors for progression from prehypertension to hypertension: A 12-year Korean Cohort Study. J. Hypertens. 2020, 38, 1755-1762. [CrossRef]

28. Pell, S.; D'Alonzo, C.A. Some Aspects of Hypertension in Diabetes Mellitus. JAMA 1967, 202, 10-16. [CrossRef]

29. Long, A.N.; Dagogo-Jack, S. Comorbidities of Diabetes and Hypertension: Mechanisms and Approach to Target Organ Protection. J. Clin. Hypertens. 2011, 13, 244-251. [CrossRef]

30. Tsimihodimos, V.; Gonzalez-Villalpando, C.; Meigs, J.B.; Ferrannini, E. Hypertension and diabetes mellitus: Coprediction and time trajectories. Hypertension 2018, 71, 422-428. [CrossRef]

31. Cheung, B.M.Y.; Li, C. Diabetes and Hypertension: Is There a Common Metabolic Pathway? Curr. Atheroscler. Rep. 2012, 14, 160-166. [CrossRef]

32. Julius, S.; Nesbitt, S.D.; Egan, B.M.; Weber, M.A.; Michelson, E.L.; Kaciroti, N.; Black, H.R.; Grimm, R.H.; Messerli, F.H.; Oparil, S.; et al. Feasibility of treating prehypertension with an angiotensin-receptor blocker. N. Engl. J. Med. 2006, 354, $1685-1697$. [CrossRef] 
33. Vasan, R.S.; Larson, M.G.; Leip, E.P.; Evans, J.C.; O’Donnell, C.J.; Kannel, W.B.; Levy, D. Impact of high-normal blood pressure on the risk of cardiovascular disease. N. Engl. J. Med. 2001, 345, 1291-1297. [CrossRef]

34. Qureshi, A.I.; Suri, M.F.K.; Kirmani, J.F.; Divani, A.A.; Mohammad, Y. Is prehypertension a risk factor for cardiovascular diseases? Stroke 2005, 36, 1859-1863. [CrossRef]

35. Booth, J.N., III; Li, J.; Zhang, L.; Chen, L.; Muntner, P.; Egan, B. Trends in prehypertension and hypertension risk factors in US adults: 1999-2012. Hypertension 2017, 70, 275-284. [CrossRef]

36. Hahka, T.M.; Fan, Y.; Jiang, E.M.; Chen, Q.; Shan, Z. High Salt Diet Plus Fructose Water Intake Induces Hypertension. FASEB J. 2017, 31, lb660. [CrossRef]

37. Kirabo, A. A new paradigm of sodium regulation in inflammation and hypertension. Am. J. Physiol. Regul. Integr. Comp. Physiol. 2017, 313, R706-R710. [CrossRef]

38. Gabriel, A.C.; Bell, C.N.; Bowie, J.V.; LaVeist, T.A.; Thorpe, R.J. The Role of Social Support in Moderating the Relationship between Race and Hypertension in a Low-Income, Urban, Racially Integrated Community. J. Urban Health 2020, 97, 250-259. [CrossRef] [PubMed]

39. Deere, B.P.; Ferdinand, K.C. Hypertension and race/ethnicity. Curr. Opin. Cardiol. 2020, 35, 342-350. [CrossRef] [PubMed]

40. Young, D.R.; Fischer, H.; Arterburn, D.; Bessesen, D.; Cromwell, L.; Daley, M.F.; Desai, J.; Ferrara, A.; Fitzpatrick, S.L.; Horberg, M.A.; et al. Associations of overweight/obesity and socioeconomic status with hypertension prevalence across racial and ethnic groups. J. Clin. Hypertens. 2018, 20, 532-540. [CrossRef] [PubMed] 